\title{
Individual resilience, pleasure, and suffering at work and organizational links: reflections and perspectives of research for the public sector
}

\author{
FABIO FAIAD BOTTINI ${ }^{1}$ \\ Kely César Martins de Paiva ${ }^{1}$ \\ RICARDO C. GOMES ${ }^{2}$
}

\author{
${ }^{1}$ Universidade Federal de Minas Gerais (UFMG) / Departamento de CiÊnCIAS AdMinistrativas, Faculdade de CIÊnCIAS \\ ECONÔMICAS, BELO HORIZONTE - MG, BRAZIL

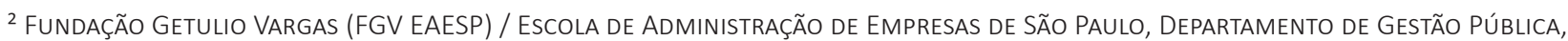
SÃO PAULO - SP, BRAZIL

\begin{abstract}
The Brazilian public sector is peculiar, given its idiosyncrasies and problems. This work environment directly affects people and can be experienced as a source of pleasure or suffering, depending on how the subject-worker perceives and adapts, which has been analyzed based on the concept of individual resilience. The level of resilience can influence how and why individuals are connected to the organizations where they work. Academic researchers and market professionals have examined these issues since they impact workers' health and organizational performance. In this theoretical essay, the three themes (Individual resilience; Pleasure and suffering at work; Organizational links) are presented. Also, the study offers an integrative model that allows a broader and deeper view of the phenomena and their possible interrelations, raising hypotheses that can guide future studies. A future research agenda, including methodological aspects, is proposed to stimulate epistemological possibilities and varied research perspectives.
\end{abstract}

Keywords: Individual resilience. Pleasure and suffering at work. Organizational links. Public sector.

Resiliência individual, prazer e sofrimento no trabalho e vínculos organizacionais: reflexões e perspectivas de pesquisas para o setor público

\section{Resumo}

O setor público brasileiro se apresenta como um caso peculiar, dados os seus problemas e as suas idiossincrasias. Tal ambiente de trabalho afeta diretamente as pessoas, podendo ser vivenciado como fonte de prazer e/ou sofrimento, a depender de como o sujeito-trabalhador o percebe e a ele se adapta, o que tem sido analisado à luz do conceito de resiliência individual. De igual modo, o nível de resiliência pode influenciar as maneiras e os motivos pelos quais os indivíduos se vinculam às organizações em que trabalham. Essas questões têm sido alvo de atenção por parte de pesquisadores-acadêmicos e de profissionais do mercado, já que têm impacto na saúde do trabalhador e no desempenho organizacional. Neste ensaio teórico são apresentados os três temas (Resiliência individual; Prazer e sofrimento no trabalho; Vínculos organizacionais), finalizando-se com um modelo integrativo que permite uma visão mais ampla e profunda dos fenômenos e de suas possíveis inter-relações, tendo sido levantadas hipóteses que podem nortear estudos futuros. Com base nisso, propõe-se uma agenda de investigações futuras, incluindo aspectos metodológicos, a fim de estimular possibilidades epistemológicas e perspectivas de pesquisas variadas.

Palavras-chave: Resiliência individual. Prazer e sofrimento no trabalho. Vínculos organizacionais. Setor público.

Resiliencia individual, placer y sufrimiento en el trabajo y lazos organizacionales: reflexiones y perspectivas de investigación para el sector público

\section{Resumen}

El sector público brasileño presenta un caso peculiar, dados su idiosincrasia y sus problemas. Este ambiente de trabajo afecta directamente a las personas y puede ser experimentado como una fuente de placer y/o sufrimiento, dependiendo de cómo el sujeto trabajador lo perciba y se adapte a él, lo cual ha sido analizado a la luz del concepto de resiliencia individual. Asimismo, el nivel de resiliencia puede influir en las formas y razones por las cuales los individuos se vinculan con las organizaciones donde trabajan. Estos temas han sido objeto de atención por parte de investigadores académicos y profesionales del mercado, ya que tienen un impacto en la salud de los trabajadores, así como en el desempeño organizacional. En este ensayo teórico se presentan los tres temas (Resiliencia individual; Placer y sufrimiento en el trabajo; Lazos organizacionales), terminando con un modelo integrador que permite una visión más amplia y profunda de los fenómenos y sus posibles interrelaciones. Además, se plantean hipótesis que pueden guiar futuros estudios. A partir de ello, se propone un programa de investigaciones futuras, incluidos los aspectos metodológicos, a fin de estimular las posibilidades epistemológicas y las variadas perspectivas de investigación.

Palabras clave: Resistencia individual. Placer y sufrimiento en el trabajo. Lazos organizacionales. Sector público. 


\section{INTRODUCTION}

The changes taking place in the business environment and in the world of work, triggered by globalization, constant technological advancement, and increasing competitiveness have led individuals to plan their careers more and more, by setting professional goals and carrying out strategies to achieve them (Moura, Silva \& Carvalho, 2019). The same occurs in Brazilian public administration, whose varied and growing demands have given rise to discussions about the size, legitimacy, efficiency, and performance of States (Filardi, Castro \& Zanini, 2020).

The increased pressure for agility and results, as well as fear and anxiety, have impacted workers in various ways, such as burnout syndrome (Pfeffer, 2018), occupational stress, workplace malaise (Gaulejac, 2007), and other situations involving psychological and physical violence (Hirigoyen, 2011). In this scenario, the issue of pleasure and suffering in the workplace has come to play an important role in debates about the world of work. The work environment directly affects individuals, who can perceive it and experience it as physically and mentally harmful or healthy, regardless of their level of education, occupation, business sphere, location, age group, etc. (Pfeffer, 2018).

The reaction of individuals to such demands seems to depend on how they adapt (or fail to adapt) to such transformations, which are typical of the contemporary world (Benedicto, Brito \& Lima, 2005), especially in the scope of work and labor. In this context, more resilient individuals tend to be more able to perform their duties and sustain healthy working conditions. In times of economic uncertainty and intense competition, organizations that promote resilience among their workers have a clear advantage over others (Malik \& Garg, 2018). Therefore, resilience, that is, the ability to absorb and react to uncomfortable and challenging situations, is imperative in such environments (Irigaray, Paiva \& Goldschmidt, 2017).

The study of resilience in organizations sheds light on the new conventions in human labor and helps to identify the characteristics of the new professional, in addition to their importance in a given organization (Teixeira \& Queiroz, 2013), as well as the direct impacts on how (and why) workers establish their ties with their organizations.

As for the forms of organizational ties, we must first highlight commitment, which has acquired increased importance among scholars and professionals, for it operates in empirical terms and presents itself as a potential predictor of favorable individual performances to social actors in the workplace. Therefore, this concept has been intensively analyzed and debated in the last decades (Mariano \& Moscon, 2018). In addition, entrenchment and consent are also presented herein.

On the one hand, many workers think of quitting their jobs but change their minds because of long-term security, in face of the widespread and growing layoffs, and the lack of opportunities in the labor market. This attitude refers to entrenchment, a metaphor that relates to the continuity of workers in a given job or career because the change is impossible or disadvantageous to them (Silva, Lima \& Leone, 2015). On the other hand, the veiled restriction on freedom may cause workers to behave in accordance with company policies, in a clash between ambiguity in behavior and survival in the face of eventualities. Therefore, the passing of time is an important factor that promotes the subjects' consent to the management modes, making them more available and submissive to their management and the organization to which they are tied (Grisci, Cigerza \& Hofmeister, 2006).

Regarding resilience, organizational ties, and pleasure and suffering in the workplace, the public sector shows different outlines, especially in Brazil, where certain legal protections and counterproductive behaviors that lack management and leadership are in force (Bergue, 2019). Public management now faces difficulties thanks to the political and economic crises, but it has a long history as a field of research and practice. Indeed, it has received close attention from Brazilian researchers (Aguiar \& Santos, 2017). This sector has been widely questioned in the face of the inefficiency resulting from an excessively bureaucratic apparatus and the low level of engagement of managers and employees (Vidal \& Rodrigues, 2016), despite efforts undertaken for the development of leaders and sector-specific skills (Bergue, 2019). Civil servants, whether they exercise a managerial function or not, can be affected, as mentioned before, by everyday experiences in which suffering overlaps pleasure and resilience is not sufficient to maintain the desired levels of productivity and quality while keeping in mind the sector's typical hierarchical structures and bureaucratic processes (Bergue, 2019). 
Studies on organizational ties still need further exploration, as research on commitment, which already had a history in the country, opened space for discussion of entrenchment and consent (Balsan, Kneipp, Tonin \& Costa, 2016). Therefore, this reflection meets an open research agenda, which deals with commitment, entrenchment (Santos, 2017), and consent (Tomazzoni, Costa, Antonello \& Rodrigues, 2020). The same is true of studies on resilience (Irigaray et al., 2017), especially in the sector focused herein (Carvalho, Teodoro \& Borges, 2015). In turn, research on pleasure and suffering in the workplace has a somewhat more consolidated trajectory in the country, which comprises the sector in question (Aguiar \& Santos, 2017). However, the current demands of the public sector, which include threats to labor rights and work overload resulting from pensions and hiring challenges, incite reflections on the possible connections with other topics dealt with in the field of organizational behavior.

Given this context and the themes involved, a discussion emerges around the causal relationships between individual resilience, pleasure and suffering in the workplace, and organizational ties. To support it, this essay is organized into the following sections: this introduction, the conceptual references of the central constructs - individual resilience, pleasure and suffering in the workplace, and organizational ties -, arguments on the possible relations between constructs and the proposition of the integrative model, as well as research perspectives and final remarks.

\section{ON INDIVIDUAL RESILIENCE}

In light of the challenges imposed by the market and society, the interest of both researchers and professionals in resilience in the workplace has grown in the last decade (Hartmann, 2018), in an attempt to understand how people deal with adversity (Rogge \& Lourenço, 2015) and, as a result, may experience a decline in their performance (Stoverink, Kirkman, Mistry \& Rosen, 2018), with potential consequences for their well-being.

The concept of resilience comes from engineering, more specifically from the first studies on the elasticity of materials (Sabbag, 2017). In psychology, the discussion of resilience began in the 1970s (Irigaray et al., 2017), and has been recently assimilated by management, focusing on one's ability to adapt to significant changes in organizations (Irigaray et al., 2017; Sabbag, 2017). In this field of knowledge, two levels of analysis of resilience have been outlined, namely people in the organizational environment and organizations. Studying resilience in that field allows the exploration of factors that directly impact the performance of companies in their (macro) environments and people in their (micro and meso) professional environments, with repercussions on short and long-term organizational results (Irigaray et al., 2017).

Focusing on individual resilience and considering the complexity of human behavior, its reactions, satisfactions, dissatisfactions, weaknesses, and fears that put pressure on the psychic apparatus, resilience becomes more of a defense or coping mechanism in the personal and professional fields (Vieira \& Oliveira, 2017), after all

resilience is not a linear process, determined in advance from certain causes that always and necessarily produce the same effects. It depends on the complex and never predictable interactions of innumerable variants. However, it is favored by two essential elements, although not always sufficient in themselves: ties and meanings. It is the subjects themselves who promote their resilience when they find significant ties that allow them to reconstruct meaning. Then, the others come to play the role of resilience tutors (Condorelli, Guimarães \& Azevedo, 2010, p. 116).

For the purposes of this essay, resilience is understood as a phenomenon characterized by positive adaptation results in the face of negative experiences, which allows one to overcome stressful and adverse situations (Carvalho et al., 2015). Therefore, the investigation of risk and protective factors in interaction is a paramount condition to analyze it. The expression "in interaction" highlights the active character of resilience, as opposed to an assumed passivity that implies the sole avoidance of harm face to discomforts and setbacks; instead, it means that one can actively improve through them (Taleb, 2012).

Despite being critical in the context of submitting workers to precarious and/or violent conditions in the workplace, the concept of resilience aims to expose the underlying reasons for this human experience in the face of adversity, which encourages critical researchers to reexamine their assumptions about the theme (Van Breda, 2018). 
Considering, from this perspective, resilience in the work context, one can say that the risks are represented by situations of tension, pressure, and transformation taking place in the organizational environment and that the protection mechanisms would occur not only according to the worker's characteristics but also the environmental conditions in terms of social support from co-workers, organizational support (provided by the organization's power structure, division of duties, its functional dynamism, material infrastructure, etc.) and support from family members (intra and extra-organizational resources) (Carvalho et al., 2015, p. 208).

Therefore, the way a given individual reacts to everyday situations and tensions can lead them to experience feelings of pleasure and/or suffering in the workplace, as well as affect their ties with the organization.

\section{ON PLEASURE AND SUFFERING IN THE WORKPLACE}

Work is paramount in society not only for individuals to produce and survive, but also to fulfill and structure themselves psychically. The way subjects relate with these subjective and objective aspects can result in experiences of pleasure and/or suffering in the workplace (Salgado, Aires \& Santos, 2018), which are objects of the psychodynamics of work. This field focuses on the relationship between workers and the organization of work and considers the dimensions of context and content operating in such an organization (Aguiar \& Santos, 2017).

The trajectory of the psychodynamics of work is marked by three articulated phases, which are regarded as complementary (Dejours, 2007). The first dates back to the 1980s and is based on the pioneering work of Dejours (1987), which dealt with the psychopathology of work, focused on the origin of suffering from the confrontation of the subject-worker with the organization of work. The second, dating from the mid-1990s, was the moment of creation/construction of a particular and pioneering approach to study work, named "psychodynamics of work", which focused on the experiences of pleasure/suffering as dialectical and inherent to the entire work context, as well as the strategies used by workers to confront the organization of work, maintain their good health, avoid illness and ensure productivity. Finally, the third, which has lasted from the late 1990s to the present day, is characterized by the consolidation and propagation of psychodynamics as a scientific approach capable of explaining the effects of work on the processes of subjectification, sociopsychic pathologies, and occupational health.

According to Dejours (2007), normality - although only apparent - is an achievement that stems from the creation of individual and collective strategies to defend workers against suffering in the workplace and its potential reframing from the psychic and social engines of pleasure. These "engines" are directly related to individual resilience, as discussed before.

In Brazil, research on the psychodynamics of work gained importance with the seminal studies of Mendes (2007). According to the author, the milestones and concerns of the world of work and their role in the worker's health conditions and illness process encourage researchers to carry out numerous studies, of different natures, from different perspectives, regarding the modus operandi of work and its relationship with individuals (Mendes \& Morrone, 2010).

Given the above, and for the purposes of this essay, pleasure in the workplace is understood as the worker's experiences characterized by the presence of at least one of the following feelings: recognition, identification, pride, realization, and freedom (Mendes \& Morrone, 2010). In turn, suffering in the workplace is defined as experiences characterized by the presence of at least one of the following feelings: fear, dissatisfaction, insecurity, estrangement, disorientation, powerlessness in the face of uncertainty, alienation, vulnerability, frustration, restlessness, anguish, depression, sadness, aggressiveness, powerlessness to promote change, discouragement, physical or emotional weariness, depreciation, guilt, tension, and anger (Mendes \& Morrone, 2010).

Since this essay focuses on public organizations and, therefore, civil servants, it is assumed that the changes occurring in recent years in the management model and the notions of State and government have implied transformations in the daily relations of work within public bodies and agencies, favoring the emergence of conflicts in the face of the "new". Therefore, an opportunity emerges for problematizing the object, as it is necessary to shed light on what happens in work relationships 
in the context of the transformations of management models, at the same time that the perspectives of the psychodynamics of work are considered, for they are fruitful in promoting other understandings of the intersubjective dynamics in the face of conflicts generated by the confrontation between the desires of subject-workers and the models of organization and management of work currently in force (Aguiar \& Santos, 2017).

Such models may or may not contribute to the strengthening of ties between workers and organizations so that the former intends to remain in it or consider other alternatives for work or living.

\section{ON ORGANIZATIONAL TIES}

Understanding how organizational ties articulate, forming different patterns that impact the performance of workers, is paramount for elaborating strategies for creating, developing, and strengthening ties. This, in turn, encourages the development of patterns of beneficial ties for individuals and organizations alike (Rodrigues \& Álvares, 2020).

The notion of commitment inaugurated the evolution of organizational ties. The initial impulse for research took place in the 1970s and, in Brazil, in the mid-1980s. The lack of a single definition for organizational commitment meant that the different concepts adopted had one element in common: a positive psychological state that characterizes the workers' relationship with their company or organization and impacts their performance (Bastos \& Aguiar, 2015). Considering the three forms of commitment to the organization - affective, continuance, and normative -, the three-component model of Meyer and Allen (1987) was a pioneer in the subject, being widely adopted in research in Brazil (Bastos \& Aguiar, 2015) and abroad (Simosi, 2013).

The evolution of Brazilian research on that topic revealed the incoherence of considering individuals with different permanence conditions and other theoretical and practical problems as committed. This, in turn, led some researchers to review the delimitation of the organizational ties (Rodrigues \& Bastos, 2009). Therefore, the continuance and normative forms were set aside, towards the resumption of a more restricted definition of the organizational commitment construct, focused on the affective form (Bastos \& Aguiar, 2015). In this essay, commitment refers to a tie based on the belief and acceptance of the organization's values and objectives, as well as the intention to strive for it and the desire to maintain such a tie (Bastos \& Aguiar, 2015).

In turn, the instrumental tie was questioned as a form of real commitment. Therefore, it started to be articulated by another concept, of entrenchment, which refers to a worker's tendency to remain in a given company or organization because of the potential losses associated with their departure, such as benefits, financial advantages, investments in job adjustment, networking and other advantages that may restrict one's perception of alternative jobs that could supply them (Rodrigues \& Bastos, 2015). Unfortunately, by adopting inappropriate people management policies and practices, many companies intensify the entrench incidents among their staff in several ways, including the payment of high salaries and benefits. Along the same lines, Taleb (2018) critically points out that such ties translate into a differentiated status and end up consolidating themselves as an alternative and peculiar form of "slavery". For Rodrigues and Bastos (2015), the greater the workers' perception that they are adapted to social position and bureaucratic arrangements, together with the assessment of limited alternatives, the greater their chance of feeling or becoming entrenched. Therefore, for the purposes of this essay, the entrenchment of the individual is defined as a tie that involves the cognitive assessment of the potential loss of investments made by the worker in the company or organization and the scarcity of job opportunities in the labor market (Rodrigues \& Bastos, 2015).

Finally, the concept of "consent" was born from the normative form. In a context in which time is profitable and permeated by immediacy and "short-termness", the various influences of individual perception on human memory - such as distortion, minimization, naturalization, generalization, and depersonalization of events - can help to alleviate management actions that are harder to accept, which, in turn, could stimulate workers' resistance by comparing them with their previous modes of working (Grisci et al., 2006). Therefore, we understand organizational consent as one's tendency to obey the demands of the organization, which are personified by their bosses. It is assumed that the fulfillment of orders and norms derives from the relations of power and authority established between superiors and subordinates, as well as by the belief that superiors know best (Silva \& Bastos, 2015). 
Investigating the quality of the ties between individuals and organizations is paramount for understanding the relationships established in the work environment, as these can interfere in various dimensions of the organizational dynamics, including the individual's quality of life and the company's effectiveness, productivity, and competitiveness. One can verify involvement, identification, attachment, satisfaction, motivation, centrality, among other elements in the quality of ties. These elements, in turn, given their multiple combinations, help to define certain individual behaviors. The quality of the tie can be regarded as a reflection not only of intrinsic and attitudinal values but also of a response to the organization's culture, which can result in the value that the worker attributes to the company and the consequent work relationships established between them (Vidal \& Rodrigues, 2016).

Considering the Brazilian public sector, which is characterized by hundreds of positions and careers, wage distribution inequalities, budget distortions, low managerial autonomy, among others (Peci, 2020), the ties tend to have particularities, hence the decision to make the proposed model focus on this sector. Next, the relationships between the constructs in the aforementioned locus are discussed in more depth.

\section{POSSIBLE RELATIONS BETWEEN CONSTRUCTS AND PROPOSITION OF AN INTEGRATED MODEL}

Subjectivity comprises not only the workers' mind and body but a set of feelings, sufferings, ambitions, fragilities, and conflicts that shall accompany them wherever they are (Vieira \& Oliveira, 2017), in and outside the work environment. Similarly, the degree of resilience of workers is linked to their life trajectory, projects, dreams, and desires, as well as their hopes and achievements - aspects largely ignored by organizations, but strongly connected with pleasure and, therefore, with suffering in the workplace.

Suffering is perceived as a form of drama, which mobilizes the subject in the world and the workplace, in a quest to achieve health conditions. Neither suffering nor individual and collective defense strategies is pathological, but instead, ways to achieve one's health. From this perspective, intervening in the organization of work means contributing to the health process, which allows subjects to subvert suffering, hence transforming it into something endowed with meaning, intelligibility, and action. This does not mean the cancellation of the feeling, but its transformation into the pleasure of reappropriating the experience of action (Martins \& Honório, 2014, p. 848).

Therefore, pleasure and suffering in the workplace contain both objective and subjective elements that lack understanding and management, given their inherent contradictions, which are observed here in terms of their contradictions and complementarities. Given this, there is a direct and positive relationship between the workers' resilience and pleasure in the workplace, thanks to the importance of the latter in life, in a broader way, regarding personal and professional fulfillment and respect for one's identity as a psychological and social subject, who produces and recognizes oneself in their relation to others (Mendes \& Morrone, 2002). An example of this was presented in a study on the public sector, with the participation of female military policemen, in the state of Minas Gerais, in which the results related to pleasure were more significant than those related to suffering. However, the subjects pointed to the need for continuous resilience in order to achieve that, including their need to overcome their male colleagues in terms of their results, and render their feminine traits unfeasible (Carmo, Guimarães \& Caeiro, 2016).

Another relevant factor deals with the conditions under which one's work is carried out, which can turn it into something painful and lead subjects to suffering arising from the confrontation between their subjectivity and the restrictions in force in their socio-cultural and environmental contexts, social relations, and organization of work. An example of this is moral harassment and other forms of violence in the workplace. Indeed, studies have shown how resilience can mitigate the pain resulting from the humiliations and misfortunes imposed on workers (Bacchi, Carvalho \& Pinto, 2012).

There is a direct and negative relationship between the worker's individual resilience and their degree of suffering in the workplace. The most resilient workers resignify suffering and transmute it into a stimulus for change and the construction of defense strategies, as suffering is not pathological in itself, but can serve as an alert to subjects so that they can carry out actions aimed at preventing illness (Mendes \& Morrone, 2002). In this case, there is an example of a study conducted with judges and officials of the Judiciary on resilience and stress control in the workplace. The research revealed that the greater 
the skills to analyze the causes of adversity, control one's emotions, take on an optimistic attitude in the face of life, understand the reasons that make other people act in a certain way, and believe in one's capacity to accomplish the tasks assigned to them, the lower the risks of developing chronic stress and related pathologies (Oliveira, 2007). That is,

in the face of stressors, individuals adopt coping strategies, which also have cognitive, behavioral, and emotional components. These strategies are certainly influenced by one's personality. However, it is the set of personality traits and coping strategies that form one's resilience, as a way of facing life and the ability to cope with stressful situations (Sabbag, 2017, p. 13-14).

Likewise, increasing and generic recommendations to the field of human resource management in organizations incite the search for interactivity and communication in order to retain talents, share experiences and achieve continuous motivation (Costa \& Moura, 2018). These recommendations directly imply the workers' organizational ties, especially regarding their emotional commitment, after all, the self-management of one's career can generate ambiguous effects, as well as outsourcing and personnel reduction processes, which tend to weaken the psychological contracts established between organizations and employees. Similarly, the decrease in organizational commitment may stem from the organization of work around autonomous teams, consisting of professionals committed to each other. It is also necessary to reflect on the growing weakening of most workers' unions, which leads to a loosening of collective relations and enhances individualism. This, in turn, can have positive effects in terms of organizational commitment and personal career (Borges-Andrade \& Pilati, 2001). Therefore, a risky movement is identified, from the point of view of the organization, caused by the promotion of affective involvement and, at the same time, the establishment of personnel policies based on the volatility of work (Borges, Lima, Vilela \& Morais, 2004).

Given the above, one can conclude the existence of a direct and positive relationship between the workers' individual resilience and their organizational ties. In other words, the more resilient individuals are, the more they become emotionally attached to the organization, and the more they disregard the possibility of leaving it. Therefore, satisfactory material and symbolic exchanges between organizations and workers are necessary to achieve a higher degree of quality of life in the workplace, as well as greater productivity (Vidal \& Rodrigues, 2016).

In the case of Brazilian civil servants, there is a diversity of careers with different rem unerations, fields of activity, incentives, and development trajectories. This diversity, in turn, makes such careers attractive and disputed even when the remuneration level among them is similar (Santos, 2017). In addition, Brazilian civil servants count on institutional protections that can contribute to the development of their resilience, insofar as anyone can resort to certain mechanisms (administrative processes, leaves, etc.) to face potential threats, mitigate their suffering, and favor their adaptation, or even the presence of certain forms of professional recognition and freedom of speech that promote pleasure in the workplace. Indeed, organizational ties can be strengthened - or weakened - through utilitarian uses of such mechanism, taking advantage of the social relations taking place within certain working environments. For instance, a comparative study between Brazilian and Norwegian civil servants pointed out that, despite the differences in organizational and national culture, resilience plays a relevant role in the socialization results (Carvalho et al., 2015). This points to different possibilities in terms of organizational ties, regardless of whether commitment, consent, or entrenchment are considered, with different impacts on one's performance (Santos, 2017).

Given the relationships observed in the literature and Brazilian studies, the concepts of individual resilience, pleasure, and suffering in the workplace, as well as organizational ties, tend to be treated separately, although research recommendations are fruitful regarding the development of integrative approaches that address them together, while aiming to contribute to human resource management and the public service in particular, in the sense of implementing policies that establish a healthier and more productive relationship between individuals and their activities.

Therefore, to propose an integrative model, the following hypotheses are postulated:

1. There is a positive relationship between the worker's resilience and pleasure in the workplace.

2. There is a negative relationship between the worker's resilience and suffering in the workplace.

3. There is a positive relationship between the worker's resilience and their commitment.

4. There is a positive relationship between the worker's resilience and their consent.

5. There is a positive relationship between the worker's resilience and their entrenchment. 
6. There is a positive relationship between pleasure in the workplace and the worker's commitment.

7. There is a positive relationship between pleasure in the workplace and the worker's consent.

8. There is a positive relationship between pleasure in the workplace and the worker's entrenchment.

9. There is a negative relationship between suffering in the workplace and the worker's commitment.

10. There is a negative relationship between suffering in the workplace and the worker's consent.

11. There is a negative relationship between suffering in the workplace and the worker's entrenchment.

These hypotheses are presented in the proposed model for an integrated study of the constructs analyzed in Figure 1:

\section{Figure 1}

Integrative model between individual resilience, pleasure, and suffering in the workplace and organizational ties

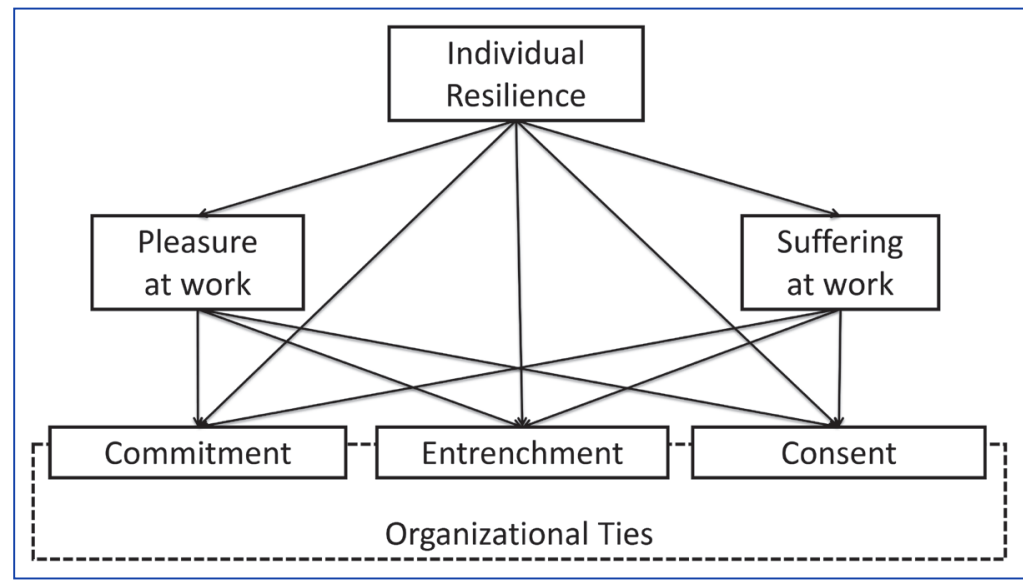

Source: Elaborated by the authors.

Such hypotheses can also be rethought in terms of guiding questions in studies of an analytical and interpretative nature. This movement creates opportunities for a future research agenda that includes diverse methodological conceptions and approaches, as well as methods and possibilities for theoretical and methodological triangulation, along the lines indicated by Collis and Hussey (2005). Some of these possibilities are presented in the next section.

\section{SUGGESTIONS FOR FUTURE RESEARCH AND FINAL REMARKS}

The themes discussed here are complex and can be interpreted and analyzed from a variety of perspectives. However, despite the proposed model, some ontological possibilities, which favor objective realism or subjective nominalism, and epistemological - functionalist, positivist, structured, and causal or analytical, phenomenological, relative, and relational - seem to impose themselves, usually through how the research problem is constructed and how the investigations are conceptually and pragmatically conducted.

Due to its depth, the qualitative approach comes close to the complexity present in the themes presented but may incur limitations regarding comparisons and generalizations (Silva, Medeiros \& Enders, 2011). The quantitative approach is more advanced concerning the aspects that the qualitative one cannot support but may incur in superficial analyses that fail to reach the essence of the phenomena (Silva et al., 2011), particularly when analyzed in an integrated fashion. Therefore, regarding the methodological perspectives for future research, we suggest that quantitative and qualitative approaches be adopted, as well as conjugated methods or triangulations (Collis \& Hussey, 2005). 
Regarding the quantitative approach, it is advisable to incorporate uni, bi, and multivariate statistical techniques, including structural equation modeling, to verify the potential effects of one or more variables on the others (Hair, Black, Babin \& Anderson, 2004). As a matter of fact, this would be the most suitable approach for the quantitative validation of the integrative model proposed herein. When testing the influence and significance between the variables of the integrated constructs, it is possible to verify the type of association (direct, mediator, or moderator) that would best describe the interrelationships between them (Hair et al., 2004). By collecting the results of such broad investigations, it would be possible to develop other instruments for collecting more extensive data (inventories, scales, questionnaires), aiming at building more robust models.

Regarding organizational ties, the three forms feature recently validated scales: The "Organizational Commitment Questionnaire" by Bastos and Aguiar (2015), the "Organizational Consent Scale" by Silva and Bastos (2015), and the "Organizational Entrenchment Questionnaire" by Rodrigues and Bastos (2015). The first two are unidimensional, whereas the third (entrenchment) is three-dimensional and can measure adaptation, social position, impersonal bureaucratic arrangements, and the limitations of worker-respondent alternatives.

As for resilience, the concept would have limited applicability if it could not be observed, analyzed, and measured in individuals (Sabbag, 2017). Along these lines, Carvalho et al. (2015) validated in Brazil the "Adult Resilience Scale", originally developed by Norwegian scholars. It consists of six factors: self-perception, planned future, social competence, structured style, family cohesion, and social resources. Such scales can be useful in quantitative research based on the proposed integrated model.

The works of Mendes (2007) opened up a new possibility of understanding the phenomenon related to the pleasure-suffering dyad in the workplace and the defense strategies of workers, moving from the analytical and interpretative conception, originally inaugurated by Dejours, to a functionalist and positivist one. Therefore, Mendes and Ferreira (2007) proposed four interrelated categories or dimensions of analysis for the study of psychodynamics: the work context, which refers to the organization, the socio-professional relations, and the work conditions; the demands of work, related to the physical, cognitive and affective cost of the activities involved; the meaning of work, directly related to the experiences of pleasure and suffering in the workplace; and finally, the effects of work on health, in terms of the consequences and the physical and psychosocial damage of a given work over workers.

Such dimensions can be assessed independently with a research instrument called "Inventory on Work and Illness Risks" (ITRA), which has been widely adopted in Brazil. ITRA was created and validated by Mendes and Ferreira (2007) in an extensive survey with Social Security tax auditors and, later, revalidated by the authors themselves in a new survey with the participation of other federal civil servants (Ferreira, Santos, Paula, Mendonça \& Carneiro, 2017), hence demonstrating the suitability of the instrument for studying public organizations.

In turn, the qualitative approach would allow the in-depth understanding of focused phenomena and the relationships between them, as well as the further understanding of quantitative data, in the case of triangulations. In addition, qualitative methods could identify other categories of analysis and variables, including those more pertinent to the public sector, hence enabling the development of more robust models with greater understanding and explanatory power, as pointed out by Abdalla, Oliveira, Azevedo and Gonzalez (2018). This, in turn, could lead to adaptations in the existing scales and the development of more specific measures for the public sector.

Regarding the public sector differences at the federal, state, and municipal levels are considered, as well as in their fields of expertise. As noted by Aguiar and Santos (2017), direct and indirect administration are also included, as well as institutions belonging to the three branches: Executive, Legislative, and Judiciary. Relationships between commitment and entrenchment have been discussed in other studies (Milhome \& Rowe, 2018), and some studies have focused on the public sector (Santos, 2017; Silva, Tomazzoni \& Costa, 2018). The analysis by Botelho and Paiva (2011), carried out in a court of the judicial branch of the state of Minas Gerais, pointed out possibilities of thematic connections with the commitment construct and the need for triangulated studies. For instance, this was done by Costa, Oliveira and Nogueira (2017), in a study that adopted the quantitative approach and recommended studies with triangulation in other court levels of the Brazilian judicial branch. Another study conducted at a research institute revealed different levels of commitment between civil servants and outsourced workers (Paiva, Falce \& Muylder, 2013). This also suggested further investigation through triangulation, based on the proposed theoretical model. Along these lines are the recommendations present in the essay written by Irigaray et al. (2017) addressing resilience and its possible thematic connections, which include the public sector and the highlighted fields, as well as workers with differentiated labor ties within the same public organization, such as civil servants, employees, and outsourced workers. 
Another relevant aspect regarding the everyday life in the public sector is the exercise of the managerial function, usually "temporary" for positions of trust and packed with difficulties as far as the technical careers are concerned, which can be observed in the research conducted by Dutra, Oleto, Paiva and Rios (2016). Likewise, the development and performance of leaders (Bergue, 2019) of employees in management positions can be facilitated by the knowledge of individual and preeminent characteristics in groups of servants, such as those that relate to their adaptation capacities (resilience), to their ways of experiencing positively or negatively the work they perform (pleasure and suffering) and how they connect to the organization, either affectively (commitment), out of loyalty to their managers (consent), or for lack of more advantageous options (entrenchment). Such knowledge can promote and facilitate social relations and, in particular, the exercise of the managerial function and public service management itself.

Finally, these studies point out differences that must be brought to light in the scope of the public sector, more precisely regarding the government's performance in areas such as education, health, and public safety, among others. Relevant analyses have been conducted in federal institutions of technical and higher education regarding the subjects addressed herein, as is the case of pleasure and suffering in the workplace (Dario \& Lourenço, 2018), and also focusing on hospital organizations, as in the study conducted by Barros and Honório (2015).

The vastness of the Brazilian public sector has proven fruitful for research in various fields, due to the pragmatic peculiarities observed in previous studies, based on the sector's scope and high complexity (Cavalcante, 2018). Such aspects, as well as their consequences in the staff of established civil servants, are suggestions for future research.

This article has not aimed to restrict or exhaust the discussion around the themes discussed herein, but achieve the objective of proposing an integrated model for this research agenda, which serves two instances: (1) the conceptual and academic, which aims to outline and expand the delimitation of the constructs involved through the integrative model, and (2) the practical and professional, which aims to provide inputs and subsidies to achieve a more humane and effective form of human resource management in the public sector.

\section{ACKNOWLEDGEMENTS}

We thank the support from the National Council for Scientific and Technological Development (CNPq). 


\section{REFERENCES}

Abdalla, M. M., Oliveira, L. G. L., Azevedo, C. E. F., \& Gonzalez, R. K. (2018). Quality in Qualitative Organizational Research: Types of Triangulation as a Methodological Alternative. Administração: Ensino e Pesquisa, 19(1), 66-98.

Aguiar, R. G., \& Santos, A. C. B. (2017). Conflitos nas relações sociais de trabalho no contexto da nova gestão pública à luz da psicodinâmica do trabalho. Race - Revista de Administração, Contabilidade e Economia, 16(esp.) 157-184.

Angelis, C. A. (2013). Uma proposta de um modelo de inovação e inteligência governamental. Revista de Administração e Inovação, 10(3), 97-324.

Bacchi, G. A., Carvalho, D. R., \& Pinto, F. R. (2012). Assédio moral e resiliência no local de trabalho. Revista Ciências Administrativas, 18(1), 301-330.

Balsan, L. A. G., Kneipp, J. M., Tonin, S., \& Costa, V. M. F. (2016). Os vínculos que o indivíduo estabelece com a organização: uma análise da produção científica brasileira. Revista de Ciências da Administração, 8(45), 25-37.

Barros, N. M. G. C., \& Honório, L. C. (2015). Riscos de adoecimento no trabalho de médicos e enfermeiros em um hospital regional mato-grossense. Revista de Gestão, 22(1), 95-113.

Bastos, A. V. B., \& Aguiar, C. V. N. (2015). Comprometimento organizacional. In K. Puente-Palacios, A. L. A. Peixoto (Eds.), Ferramentas de diagnóstico para organizações e trabalho: um olhar a partir da psicologia (pp. 78-91). Porto Alegre, RS: Artmed.

Benedicto, S. C., Brito, M. J., \& Lima, J. B. (2005). Aprendizagem transformativa no espaço organizacional: uma análise da proposta andragógica da Petrobras. Organizações Rurais e Agroindustriais, 7(1), 3-36.

Bergue, S. T. (2019). Gestão de pessoas: liderança e competências para o setor público. Brasília, DF: Enap.

Borges, L. O., Lima, A. M. S., Vilela, E. C., \& Morais, S. S. G. (2004). Comprometimento no trabalho e sua sustentação na cultura e no contexto organizacional. Revista de Administração de Empresas, 3(1), 1-24.

Borges-Andrade, J. E., \& Pilati, R. (2001). Comprometimento atitudinal e comportamental: relações com suporte e imagem nas organizações. Revista de Administração Contemporânea, 5(3), 85-106.

Botelho, R. D., \& Paiva, K. C. M. (2011). Comprometimento organizacional: um estudo no Tribunal de Justiça do Estado de Minas Gerais. Revista de Administração Pública, 45(5), 1249-1283.

Carmo, J. G. M., Guimarães, L. V. M., \& Caeiro, M. L. (2016). Prazer e sofrimento no trabalho: vivências de mulheres soldados da polícia militar. Farol - Revista de Estudos Organizacionais e Sociedade, 3(8), 1313-1357.

Carvalho, V. D., Teodoro, M., \& Borges, L. O. (2015). Resiliência no contexto de trabalho. In K. Puente-Palacios, A. L. A. Peixoto (Eds.), Ferramentas de diagnóstico para organizações e trabalho: um olhar a partir da psicologia (pp. 206-220).
Cavalcante, P. (2018). Innovations in the Federal Government During the Post-new Public Management Era. Revista de Administração Contemporânea, 22(6), 885-902.

Collis, J., \& Hussey, R. (2005). Pesquisa em administração: um guia prático para alunos de graduação e pós-graduação. Porto Alegre, RS: Bookman.

Condorelli, A., Guimarães, C. F., \& Azevedo, C. R. S. (2010). O bater das asas de uma borboleta: o papel do educador como tutor de resiliência à luz das ideias de Boris Cyrulnik. Interface - Revista do Centro de Ciências Sociais Aplicadas, 7(2), 114-131.

Costa, E. S., \& Moura, A. C. (2018). Motivação como fator de sucesso para a gestão de carreira: o papel do administrador na melhoria das relações de trabalho. Revista de Carreiras e Pessoas, 8(2), 212-226.

Costa, P. K. C., Oliveira, L. G. L., \& Nogueira, J. M. M. (2017). Comprometimento organizacional: um estudo de caso em um Tribunal de Justiça de médio porte da Região Nordeste do Brasil. In Anais do 6o Encontro de Gestão de Pessoas e Relações de Trabalho da ANPAD, Curitiba, PR.

Dario, V. C., \& Lourenço, M. L. (2018). Cultura organizacional e vivências de prazer e sofrimento no trabalho: um estudo com professores de instituições federais de ensino superior. Revista Organizações em Contexto, 14(27), 345-395.

Dejours, C. (1987). A loucura do trabalho: estudo de psicopatologia do trabalho. São Paulo, SP: Obore.

Dejours, C. (2007). Prefácio. In A. M. Mendes (Org.), Psicodinâmica do trabalho (pp. 19-22). São Paulo, SP: Casa do psicólogo.

Dutra, M. R. S., Oleto, A. F., Paiva, K. C. M., \& Rios, J. E. (2016). Comprometimento organizacional: um estudo comparativo entre gerentes e não gerentes do setor público mineiro. In Anais do 7 o Encontro de Administração Pública da ANPAD, São Paulo, SP.

Ferreira, L. B., Santos, M. A. F., Paula, K. M., Mendonça, J. M. B., \& Carneiro, A. F. (2017). Risco de adoecimento no trabalho: estudo com policiais militares de um batalhão de polícia de Brasília. Revista Eletrônica Gestão \& Sociedade, 11(29), 1804-1829.

Filardi, F., Castro, R. M. P., \& Zanini, M. T. F. Vantagens e desvantagens do teletrabalho na administração pública: análise das experiências do Serpro e da Receita Federal. Cadernos EBAPE.BR, 18(1), 28-46, 2020.

Gaulejac, V. (2017). Gestão como doença social. Aparecida, SP: Ideias e Letras.

Grisci, C., Cigerza, G. C., \& Hofmeister, P. M. (2006). Tempo, resistência e consentimento na reestruturação produtiva do trabalho bancário. Revista Eletrônica de Administração, 12(6), 622-641.

Hair, J. F., Jr., Black, W. C., Babin, B. J., \& Anderson, R. E. (2014). Multivariate Data Analysis. Harlow, UK: Pearson.

Hartmann, S. (2018). The Power of We: The Effects of Mutuality and Team Reflexivity on Team Resilience in the Workplace. Academy of Management Proceedings, 2018(1), 1-6. Retrieved from https:// doi.org/10.5465/AMBPP.2018.59

Hirigoyen, M. F. (2011). Assédio moral. Rio de Janeiro, RJ: Bertrand Brasil. 
Irigaray, H. A. R., Paiva, K. C. M., \& Goldschmidt, C. C. (2017). Resiliência organizacional: proposição de modelo integrado e agenda de pesquisa. Cadernos EBAPE.BR, 15(esp.), 390-408.

Malik, P., \& Garg, P. (2018). Psychometric Testing of the Resilience at Work Scale Using Indian Sample. Vikalpa - The Journal for Decision Makers, 43(2), 77-91.

Mariano, T. L. A. B., \& Moscon, D. C. B. (2018). As relações entre as práticas de gestão de pessoas e o desenvolvimento de vínculos com a organização: um estudo em uma empresa de contabilidade. Revista Gestão e Planejamento, 19, 227-243.

Martins, A. A. V., \& Honório, L. C. (204). Prazer e sofrimento docente em uma instituição de ensino superior privada em Minas Gerais. Revista O\&S, 21(68), 835-852.

Mendes, A. M. (2007). Da psicodinâmica à psicopatologia do trabalho. In A. M. Mendes (Org.), Psicodinâmica do trabalho (pp. 23-48). São Paulo, SP: Casa do Psicólogo.

Mendes, A. M., \& Ferreira, M. C. (2007). Inventário Sobre Trabalho e Riscos de Adoecimento - Itra: instrumento auxiliar de diagnóstico de indicadores críticos no trabalho. In A. M. Mendes (Org.), Psicodinâmica do trabalho (pp. 111-126). São Paulo, SP: Casa do Psicólogo.

Mendes, A. M., \& Morrone, C. F. (2002). Vivências do prazer-sofrimento e saúde psíquica no trabalho: trajetória conceitual e empírica. In A. M. Mendes, L. O. Borges, L. O., \& M. C. Ferreira (Orgs.), Trabalho em transição, saúde em risco (pp. 25-42). Brasília, DF: Editora UnB.

Mendes, A. M., \& Morrone, C. F. (2010). Trajetória teórica e pesquisas brasileiras sobre prazer e sofrimento no trabalho. In A. M. Mendes (Org.), Psicodinâmica e clínica do trabalho: temas, interfaces e casos brasileiros (pp. 29-52). Curitiba, PR: Juruá Editora.

Meyer, J. P., \& Allen, N. J. (1991). A Three-component Conceptualization of Organizational Commitment. Human Resource Management Review, 1, 61-89.

Milhome, J. C., \& Rowe, D. E. O. (2018). Comprometimento e entrincheiramento organizacional: possíveis correlações. Gestão. org - Revista Eletrônica de Gestão Organizacional, 16(1), 69-77.

Moura, A. F. G., Silva, M. R., \& Carvalho, L. C. (2019). Comprometimento organizacional: um estudo com servidores e não servidores do Tribunal de Contas de Mato Grosso do Sul. Desafio Online, 7(1), 43-67.

Oliveira, J. B. Resiliência e controle do stress em juízes e servidores públicos (Doctoral Dissertation). Centro de Ciências da Vida, Pontifícia Universidade Católica de Campinas, Campinas, SP.

Paiva, K. C. M., Falce, J. L., \& Muylder, C. F. (2013). Comprometimento organizacional: comparando servidores e terceirizados de uma fundação pública de pesquisa em saúde. Revista Economia \& Gestão, 13(33), 73-89.

Peci, A. (2020, março 05). Burocracia irracional legal. Valor Econômico. Retrieved from https://valor.globo.com/opiniao/coluna/burocraciairracional-legal.ghtml

Pfeffer, J. (2018). Dying for a Paychech: How Modern Management Harms Employee Health and Company Performance. New York, NY: Harper Collins Publishers.

Rodrigues, A. C. A., \& Bastos, A. V. B. (2009). Problemas conceituais e empíricos na pesquisa sobre comprometimento organizacional: uma análise crítica do modelo tridimensional de J. Meyer e N. Allen. In Anais do 32 Encontro da Associação Nacional de Pós-Graduação e Pesquisa em Administração, São Paulo, SP.

Rodrigues, A. P. G.; Alvares, K. P. (2020). Vínculos organizacionais: uma análise em relação ao desempenho. Revista Gestão e Planejamento, 21(1), 156-171.

Rodrigues, A. P. G., \& Bastos, A. V. B. (2013). Os vínculos de comprometimento e entrincheiramento presentes nas organizações públicas. Revista de Ciências da Administração, 15(36), 143-158.

Rodrigues, A. P. G., \& Bastos, A. V. B. (2015). Entrincheiramento organizacional. In K. Puente-Palacios, \& A. L. A. Peixoto (Eds.), Ferramentas de diagnóstico para organizações e trabalho: um olhar a partir da psicologia (pp. 107-120). Porto Alegre, RS: Artmed.

Rogge, J. F. N., \& Lourenço, M. L. (2015). A resiliência humana no ambiente acadêmico de cursos stricto sensu. Raimed - Revista de Administração IMED, 5(3), 291-301.

Sabbag, P. Y. (2017). Resiliência: competência para enfrentar situações extraordinárias na sua vida profissional. Rio de Janeiro, RJ: Alta Books.

Salgado, C. C. R., Aires, R. F. F., \& Santos, F. J. S. (2018). Dialética do "prazer e sofrimento": a relação de mestrandos e doutorandos com seu trabalho acadêmico. Contextus - Revista Contemporânea de Economia e Gestão, 16(2), 113-145.

Santos, A. P. (2017). Comprometimento e entrincheiramento em carreiras do setor público: estudo exploratório e confirmatório. Cadernos Gestão Pública e Cidadania, 22(73), 355-378.

Silva, E. E. C., \& Bastos, A. V. B. (2015). Consentimento organizacional. In K. Puente-Palacios, \& A. L. A. Peixoto (Eds.), Ferramentas de diagnóstico para organizações e trabalho: um olhar a partir da psicologia (pp. 92-106). Porto Alegre, RS: Artmed.

Silva, L. M. T., Medeiros, C. A. F., \& Enders, W. T. (2011). Avaliação da cultura organizacional: um contraponto entre as abordagens quantitativas e qualitativas. Interface - Revista do Centro de Ciências Sociais Aplicadas, 8(2), 123-140.

Silva, P. M. M., Lima, A. N. C., \& Leone, N. M. C. P. G. (2015). Entrincheiramento organizacional: percepção de empregados de uma agência bancária. Raimed - Revista de Administração IMED, 5(2), 111-120.

Silva, R. C. D., Tomazzoni, G. C., \& Costa, V. M. F. (2018). Comprometimento e entrincheiramento organizacionais: uma análise comparativa com duas instituições de ensino superior. Gestão.org Revista Eletrônica de Gestão Organizacional, 16(1), 57-68.

Simosi, M. (2013). Trajectories of Organizational Commitment: A Qualitative Study in a Greek Public Sector Organization. International Journal of Cross Cultural Management, 13(1), 111-130.

Stoverink, A. C., Kirkman, B. L., Mistry, S., \& Rosen, B. (2018). Bouncing Back Together: Toward a Theoretical Model of Work Team Resilience. Academy of Management Review, 45(2), 395-422. Retrieved from https://doi.org/10.5465/amr.2017.0005

Taleb, N. N. (2012). Antifragile: Things that Gains from Disorder. New York, NY: Ramdom House.

Taleb, N. N. (2018). Skin in the Game: Hidden Asymmetries in Daily Life. New York, NY: Ramdom House. 
Teixeira, A. R. N., \& Queiroz, R. D. (2013, agosto). A importância da resiliência no contexto organizacional. Psicologado. Recuperado de https://psicologado.com.br/atuacao/ psicologia-organizacional/a-importancia-da-resiliencia-no-contextoorganizacional.

Tomazzoni, G. C., Costa, V. M. F., Antonello, C. S., \& Rodrigues, M. B. (2020). Os vínculos organizacionais na percepção de gestores: comprometimento, entrincheiramento e consentimento. Revista de Administração Contemporânea, 24(3), 245-258.
Van Breda, A. D. (2018). A Critical Review of Resilience Theory and its Relevance for Social Work. Social Work, 54(1), 1-18. Retrieved from http://dx.doi.org/10.15270/54-1-611

Vidal, D. N., \& Rodrigues, A. P. G. (2016). Vínculos organizacionais: estudo de caso no 13으 batalhão de bombeiros militar. Revista Gestão e Planejamento, 17(1), 4-18.

Vieira, A. A., \& Oliveira, C. T. F. (2017). Resiliência no trabalho: uma análise comparativa entre as teorias funcionalista e crítica. Cadernos EBAPE.BR, 15(esp.), 409-427.

Fabio Faiad Bottini

ORCID: https://orcid.org/0000-0002-6547-435X

Ph.D. student in Administration at Universidade Federal de Minas Gerais (UFMG/FACE/CEPEAD). E-mail: fabiofaiad@bol.com.br

Kely César Martins de Paiva

ORCID: https://orcid.org/0000-0002-5185-9072

Ph.D. in Administration; Associate Professor at Universidade Federal de Minas Gerais (UFMG/FACE/CAD); CNPq Research Productivity Scholarship Level 2 (Process 312539/2018-5). E-mail: kelypaiva@face.ufmg.br

\section{Ricardo C. Gomes}

ORCID: https://orcid.org/0000-0002-4164-5986

Ph.D. in Public Management; Adjunct Professor at the School of Business Administration of São Paulo at Fundação Getulio Vargas (FGV/EAESP); CNPq Research Productivity Scholarship- Level 1D (Process 305497/2019-7).E-mail: ricardo.gomes@fgv.br 